\title{
IGF receptor function and regulation in autocrine human neuroblastoma cell growth
}

\author{
Donna M. Martin, J. Robinson Singleton, Mihir A. Meghani and Eva L. Feldman \\ Department of Neurology and the Neuroscience Program, The University of Michigan, Ann Arbor, MI (USA)
}

(Received 12 March 1993; revised version received and accepted 6 March 1993)

Key words: Insulin-like growth factor; mRNA; Proliferation; Serum; Antibody; SH-SY5Y

\begin{abstract}
Summary
Insulin-like growth factor-II (IGF-II) and its receptors (type I and II IGF receptors) are expressed in the nervous system in a tissue and developmentally specific manner. We have previously shown that SH-SY5Y human neuroblastoma cells synthesize and secrete high levels of IGF-II, and respond to it with increased neuritic outgrowth, DNA synthesis, and cell proliferation. SH-SY5Y cells also produce type I IGF and IGF-II/M6P receptors; however, it is not known whether these receptors mediate the observed growth promoting effects of IGF-II. In this study, we assayed the role of type I IGF receptor and IGF-II/M6P receptor expression in mediating autocrine IGF-II induced growth. Using anti-receptor antibodies, we found that IGF-II stimulates cell proliferation via the type I IGF receptor but not via the IGF-II/M6P receptor. By Northern analysis, we detected increased mRNA expression of both receptors, with more dramatic changes in type I IGF receptor expression. Collectively, our results indicate a role for the type I IGF receptor in mediating IGF-II induced autocrine neuroblastoma cell growth.
\end{abstract}

\section{Introduction}

Insulin-like growth factor II (IGF-II) belongs to a family of polypeptides with insulin-like metabolic and growth promoting effects on many tissues [1]. In vitro, IGF-II enhances neuritic outgrowth, DNA

Correspondence to: E.L. Feldman, 1120C Neuroscience Laboratory, 1103 E. Huron Ave., Ann Arbor, MI 48104, USA. synthesis, and proliferation of developing fetal neuroblasts [2-4], and promotes autocrine growth of neuroblastoma cells $[5,6]$. The effects of IGF-II may be due to its interactions with two different cell surface receptors, the type I IGF and IGF-II/M6P (mannose 6-phosphate) receptors [7]. The type I IGF receptor, structurally homologous to the insulin receptor, exhibits four $\left(\alpha_{2}, \beta_{2}\right)$ transmembrane spanning subunits and an intracellular tyrosine kinase 
domain [8]. The type I IGF receptor has been shown to mediate IGF-II effects on SK-N-AS neuroblastoma cell proliferation [5], and may serve a similar role in SH-SY5Y cells. In contrast, the IGF-II/M6P receptor is a single transmembrane spanning protein which exhibits separate but cooperative binding sites for IGF-II and M6P-containing ligands [9]. Its role in the intracellular trafficking of lysosomal enzymes is well established; however, the physiological relevance of IGF-II binding to this receptor is not known. Nevertheless, there is evidence that the IGFII/M6P receptor mediates IGF-II induced cell motility [10], neuritic outgrowth [11], $\mathrm{Ca}^{2+}$ influx [12], and inositol phospholipid turnover [13].

Expression of IGF-II and the type I IGF and IGF-II/M6P receptors is tissue and developmentally specific [14], and all three genes are expressed in human neuroblastoma cells $[5,15,16]$. We have previously shown that extracellular IGF-II is necessary for SH-SY5Y cell growth in serum-free media, and that IGF-II expression is sensitive to serum-induced changes in growth rate [6]. For this study, we assayed the effects of anti-IGF receptor antibodies on SH-SY5Y cell proliferation in serum-free media, and used Northern analysis to determine changes in IGF receptor expression in serum-free and serum-containing media. Anti-type I IGF receptor antibody inhibited SH-SY5Y cell proliferation in a dosedependent fashion, whereas anti-IGF-II/M6P receptor antibody had no effect on cell number. Type I IGF receptor mRNA levels increased by 6 -fold after 1 day in serum-free media, whereas IGF-II/M6P receptor levels increased by only 2 -fold. Our results implicate a definite role for the type I IGF receptor in IGF-II induced autocrine growth of SH-SY5Y cells.

\section{Materials and Methods}

Cell culture flasks were obtained from Corning Glass Works (Corning, NY), and Costar (Cambridge, MA). Calf serum (CS) and Dulbecco's modi- fied Eagle's medium (DMEM) were purchased from Gibco BRL (Gaithersburg, MD). Restriction enzymes were from Boehringer-Mannheim (Indianapolis, IN) and Gibco BRL. $\left[{ }^{32} \mathrm{P}\right] \mathrm{dCTP}$ was from NEN Dupont (Boston, MA). Monoclonal MOPC-21 antibody was purchased from Organon Teknika (Durham, NC). Murine monoclonal anti-rat IGF-II antibody was obtained from Upstate Biotechnology, Inc. (Lake Placid, NY). Polyclonal IgG against human type I IGF receptor was purchased from Oncogene Science (Uniondale, NY). Rabbit antiserum against human IGF-II/M6P receptor was generously provided by Dr. William S. Sly (St. Louis Medical Center, St. Louis, MO), and purified using an ImmunoPure (G) IgG purification kit (Pierce, Rockford, IL). All other chemicals were purchased from Sigma (St. Louis, MO).

\section{Cell culture}

SH-SY5Y human neuroblastoma cells were kindly provided by Dr. Stephen Fisher, University of Michigan Medical Center [17]. Cells were subcultured after removal with trypsin-EDTA, and routinely maintained in DMEM and $10 \% \mathrm{CS}$ at $37^{\circ} \mathrm{C}$ in a humidified atmosphere with $10 \% \mathrm{CO}_{2}$.

\section{Cell proliferation assay}

Cell proliferation was measured by the MTT colorimetric assay as previously described $[6,18]$. Cells were rinsed three times in DMEM and plated $\left(9 \cdot 10^{4}\right.$ cells $/ \mathrm{cm}^{2}$ in 96-well plates) in $100 \mu \mathrm{l}$ DMEM with or without $\alpha$-IR-3 antibody $(0.01-1.0 \mu \mathrm{g} / \mathrm{ml})$ or antiIGF-II receptor antibody $(0.03-3.0 \mu \mathrm{g} / \mathrm{ml})$ or control MOPC-21 antibody ( $1 \mu \mathrm{g} / \mathrm{ml})$. MTT (3(4,5-dimethylthiazol-2-yl)-2,5-diphenyltetrazolium bromide) was added $(1 \mathrm{mg} / \mathrm{ml})$ for a $2 \mathrm{~h}$ incubation at $37^{\circ} \mathrm{C}$. Lysis buffer $(0.1 \mathrm{ml}$ of $50 \%$ dimethyl formamide, $20 \%$ (w/v) SDS, $\mathrm{pH}$ 4.7) was then added and cells incubated at $37^{\circ} \mathrm{C}$ overnight. The absorbance $(A)$ of each well was measured by a Dynatech MR700 ELISA reader (Dynatech Laboratories, Inc., Cleveland Heights, $\mathrm{OH})$ with lysis buffer as the blank. 


\section{Northern analysis and cDNA probes}

Northern analysis was performed as reported [15]. SH-SY5Y cells $\left(2.5 \cdot 10^{4}\right.$ cells $/ \mathrm{cm}^{2}$ in T150 flasks) were cultured in DMEM/10\% CS for 2 days. Medium was then removed, cells rinsed twice in DMEM, and $\mathrm{DMEM} \pm 10 \% \mathrm{CS}$ added. RNA was isolated either immediately (no media change) or 1,2 or 3 days after this medium change. RNA $(20 \mu \mathrm{g})$ was electrophoresed in formaldehyde-agarose gels and transferred to Nytran membranes (Schleicher and Schuell, Keene, NH), then successively hybridized with $\left[{ }^{32} \mathrm{P}\right] \mathrm{dCTP}$ labelled $\left((0.1-10) \cdot 10^{8} \mathrm{cpm} / \mu \mathrm{g}\right)$ cDNA probes for human type I IGF receptor (bases 1490-2737 encoding the $\alpha$ and $\beta$ chains excised with Eco RI and Hind III) [19], human type II IGF receptor (the complete $9.1 \mathrm{~kb}$ cDNA excised with $\mathrm{Sal} \mathrm{I}$ ) [20], and chicken $\beta$-actin ( $1.8 \mathrm{~kb}$ excised with $P s t \mathrm{I})$ [21]. Using densitometry, relative $A$ for each hybridization was calculated by averaging several exposures in the linear range of the film. Experimental $A$ values were expressed as a percentage of untreated (day 0 ) controls and divided by the percentage of $A$ values similarly obtained for $\beta$-actin hybridizations.

\section{Results}

SH-SY5Y cells proliferate in serum-free media in a density- and IGF-II-dependent fashion [6]. We determined the role of the type I IGF receptor in SH-SY5Y serum-free cell division by blocking its function with the $\alpha$-IR3 blocking antibody. Cell proliferation was measured by MTT assay as described in Materials and Methods. As expected, SH-SY5Y cells exhibited a steady increase in cell number when cultured in serum-free media for 5 days (Fig. 1). Addition of $\alpha$-IR 3 induced a dose-dependent inhibition of SH-SY5Y cell proliferation, which was maximal at $0.1 \mu \mathrm{g} / \mathrm{ml}$ throughout the 5 day culture period (Fig. 1). The unrelated mouse antibody, MOPC-21, had no effect on cell number relative to serum-free control.

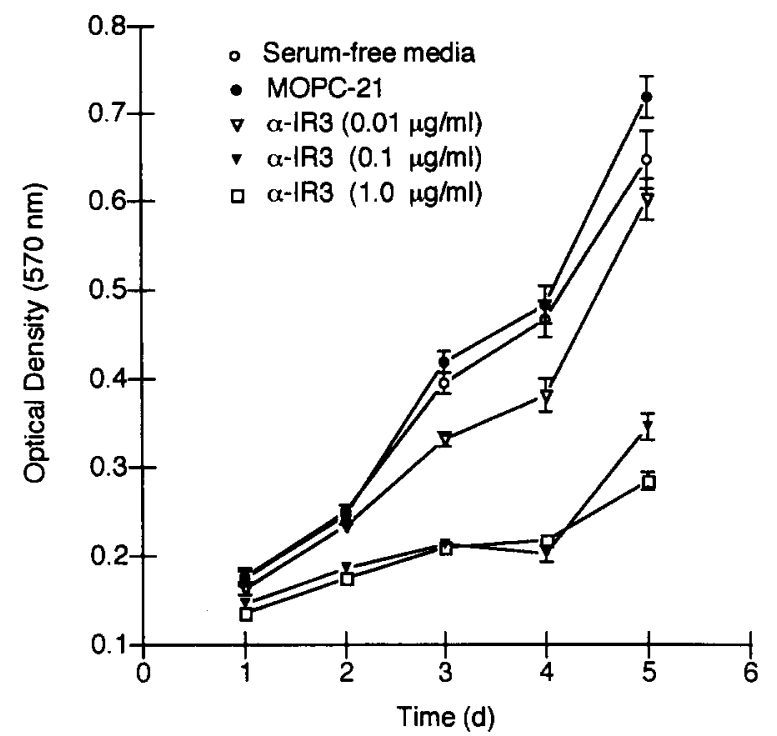

Fig. 1. Effects of type I IGF receptor antibody on SH-SY5Y cell proliferation. SH-SY5Y cells were rinsed and plated in 96-wells under various conditions, as indicated in the legend. MOPC-21 antibody was used at $1.0 \mu \mathrm{g} / \mathrm{ml}$. Cell number was measured at several subsequent time points by MTT assay. Values presented as absorbances $(570 \mathrm{~nm})$ are the means of 8 wells \pm S.E.M. from a representative experiment performed twice. Error bars omitted where too small to be seen.

As previously reported, addition of anti-IGF-II antibody also significantly reduced SH-SY5Y cell proliferation (Fig. 2) [6]. In contrast to anti-IGF-II and anti-type I IGF receptor, however, the IGF-II/ M6P receptor antibody had no effect on cell proliferation. Addition of IGF-II/M6P receptor antibody $(1-150 \mu \mathrm{g} / \mathrm{ml})$ did not alter cell number relative to the serum-free control during the entire 4-day treatment period (Fig. 2). Lower concentrations of antibody $(<150 \mu \mathrm{g} / \mathrm{ml})$ yielded growth curves similar to that for $150 \mu \mathrm{g} / \mathrm{ml}$ (data not shown).

SH-SY5Y cells express an $11 \mathrm{~kb}$ type I IGF receptor mRNA transcript and a $9.4 \mathrm{~kb}$ IGF-II/M6P receptor mRNA transcript, both of which were detectable by Northern analysis of total cellular RNA, as previously reported [15]. Using mRNA production as a representative measure of gene expression, we measured changes in mRNA levels for both the 


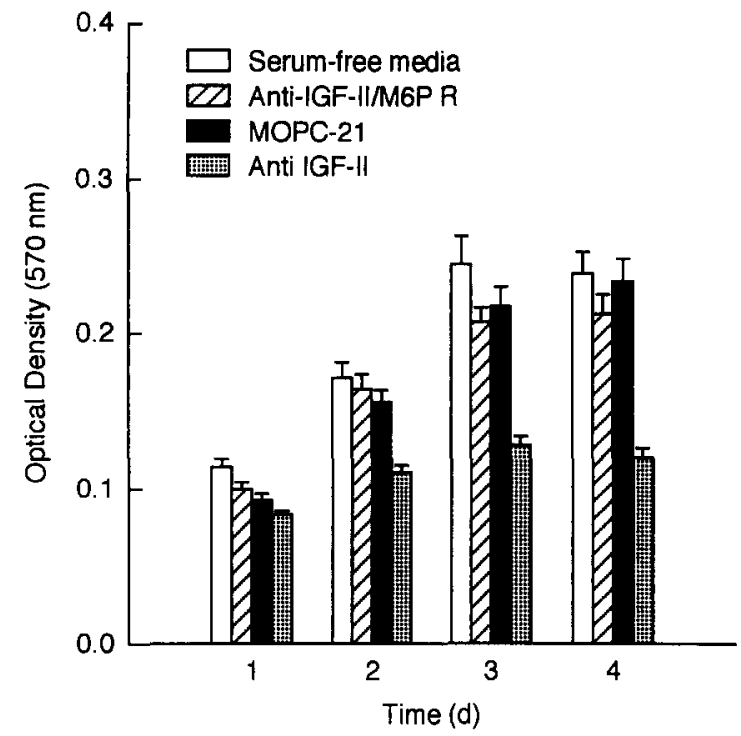

Fig. 2. Effects of IGF-II/M6P receptor antibody on SH-SY5Y cell proliferation. SH-SY5Y cells were cultured as described in Fig. 1 in the presence or absence of anti-IGF-II $(1.0 \mu \mathrm{g} / \mathrm{ml})$, MOPC-21 $(1 \mu \mathrm{g} / \mathrm{ml})$, or anti-IGF-II/M6P receptor antibody $(150$ $\mu \mathrm{g} / \mathrm{ml})$, as indicated in the legend, and MTT assay performed daily over a 4 day period. Values presented as absorbances $(570 \mathrm{~nm})$ are the means of 8 wells \pm S.E.M. from a representative experiment. type I IGF and IGF-II/M6P receptors over a 3-day period in serum or serum-free media. Levels of mRNA for the type I IGF receptor increased rapidly in the absence of serum, to 6-fold above untreated control levels after 1 day, and slowly declined thereafter, to 5-fold after 3 days (Figs. 3 and 4). Levels of the $11 \mathrm{~kb}$ type I IGF receptor mRNA transcript increased more slowly in the presence of serum, to 3 -fold above untreated control levels after 2 days, and 7 -fold above control after 3 days (Figs. 3 and 4 ). As previously reported [6], steady-state $\beta$-actin mRNA levels were decreased by $30 \%$ after 1 day in serum-free media, and were otherwise constant throughout the serum-free or serum treatment periods.

IGF-II/M6P receptor mRNA increased by 2 -fold after 1 day in serum-free media, and remained steady thereafter (Figs. 3 and 5). Like the type I IGF receptor, IGF-II/M6P receptor mRNA increased more slowly in serum, to only 2-fold above control after 3 days (Figs. 3 and 5). The observed changes in expression of the IGF-II/M6P receptor in both serum and serum-free media were much less dramatic than

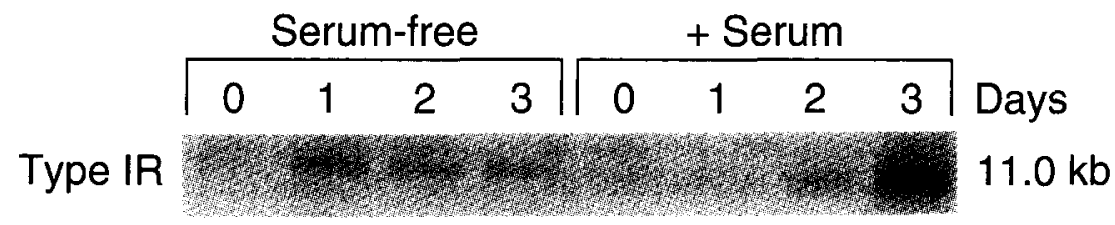

\section{IGF-II/M6P R}

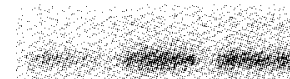

$9.4 \mathrm{~kb}$

$\beta$-actin

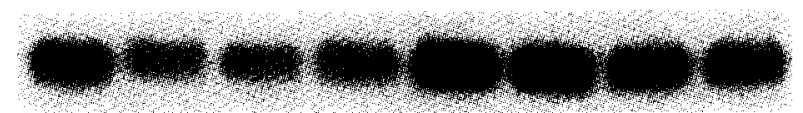

$2.1 \mathrm{~kb}$

Fig. 3. Northern analysis of mRNA for type I IGF receptor, IGF-II/M6P receptor, and $\beta$-actin. Cells were plated for 2 days in $\mathrm{DMEM}+10 \% \mathrm{CS}$, rinsed in DMEM, and fresh DMEM $\pm 10 \% \mathrm{CS}$ added. RNA was isolated either immediately or after a 1,2 , or 3 day incubation. RNA (20 $\mu \mathrm{g}$ per lane) was successively hybridized with ${ }^{32} \mathrm{P}$-labelled cDNA probes for type I IGF receptor, IGF-II/M6P receptor, and $\beta$-actin. Radiographs exposed $4 \mathrm{~d}$ (type I IGF receptor), $48 \mathrm{~h}$ (IGF-II/M6P receptor), and $48 \mathrm{~h}(\beta$-actin). 


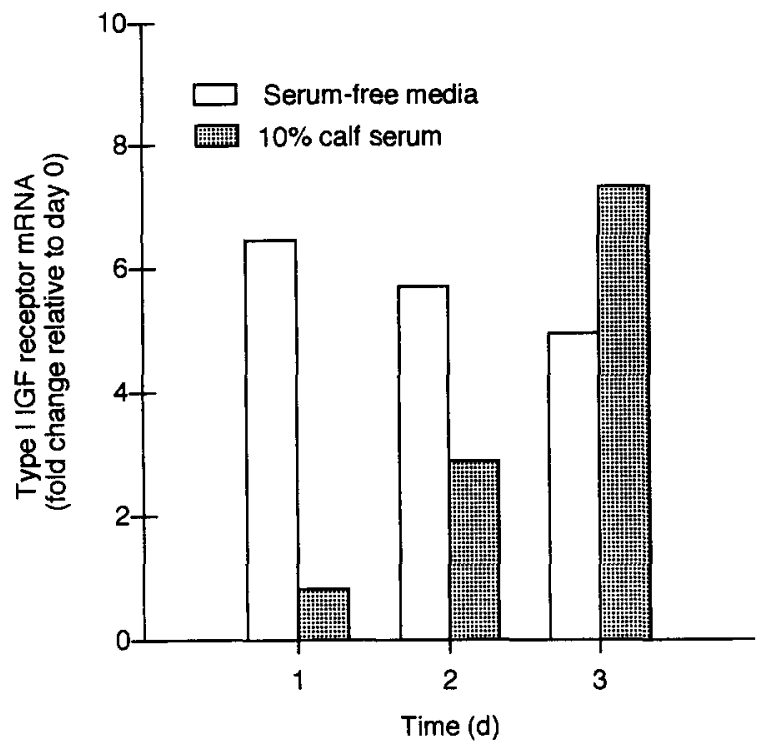

Fig. 4. Densitometric analysis of type I IGF receptor mRNA. Autoradiographs from multiple exposures of autoradiographs like those shown in Fig. 3 were quantitated as described in Materials and Methods. Values are the means of type I IGF receptor $11 \mathrm{~kb}$ mRNA transcript densities expressed as fold increase over time zero control relative to $\beta$-actin, from one of two experiments that gave similar results.

those seen for the type I IGF receptor (Figs. 4 and $5)$. Both receptors exhibited rapid increases in mRNA after transfer of SH-SY5Y cells to serumfree media, whereas mRNA levels increased more slowly in the presence of serum. These results indicate that serum exerts differential effects on IGF receptor expression, and that this expression may be rapidly increased with serum removal.

\section{Discussion}

\section{IGF receptors in autocrine growth}

We have shown in this paper that $\alpha$-IR3, a blocking antibody against human type I IGF receptor, inhibits serum-free SH-SY5Y cell growth in a dosedependent fashion. We observed weak inhibition of cell growth at $0.01 \mu \mathrm{g} / \mathrm{ml} \alpha$-IR3, and strong inhibi-

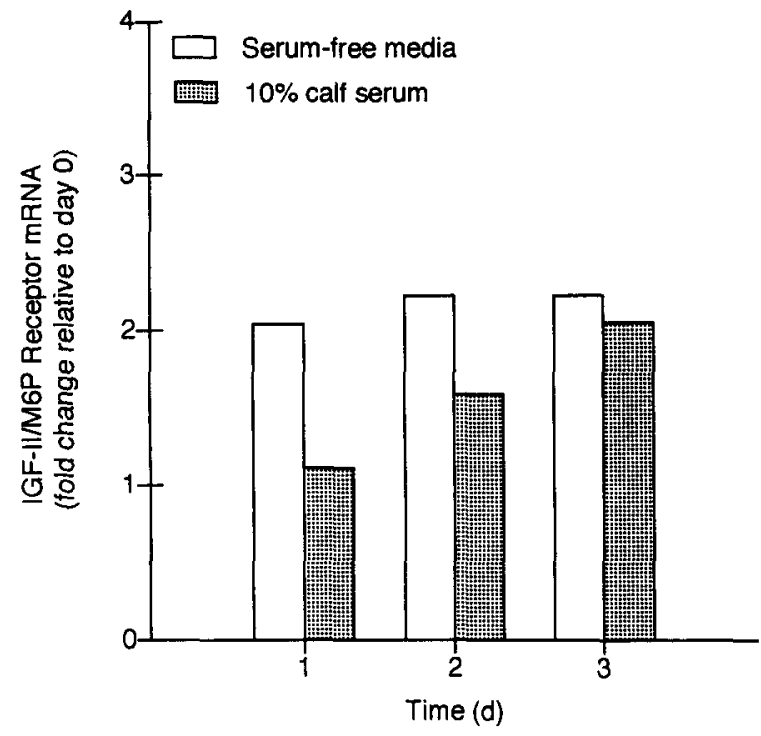

Fig. 5. Densitometric analysis of type II IGF receptor mRNA. Autoradiographs from multiple exposures of autoradiographs like those shown in Fig. 3 were quantitated as described in Materials and Methods. Values are the means of IGF-II/M6P receptor 9.4 $\mathrm{kb}$ mRNA transcript densities expressed as fold increase over time zero control relative to $\beta$-actin, from one of two experiments that gave similar results.

tion at 0.1 and $1.0 \mu \mathrm{g} / \mathrm{ml}$. These concentrations of antibody are slightly below the $2 \mu \mathrm{g} / \mathrm{ml}$ concentration used by El-Badry and colleagues to inhibit IGF-II interacting with the type I IGF receptor in SK-N-AS neuroblastoma cells [5]. Other reports have implicated the type I IGF receptor in autocrine IGF-I and IGF-II mediated growth of multiple cell types, including breast cancer [22], mouse muscle [23], and rhabdomyosarcoma [24] cells. Interestingly, SHSY5Y cells exhibited a slow growth rate even in the presence of $\alpha$-IR3 or anti-IGF-II antibodies. We interpret these results to indicate that other factors in addition to IGF-II may help sustain a low level of proliferation. Potential factors include PDGF, aFGF, b-FGF, and EGF, based on their mitogenic properties in other tissues [25].

In contrast to the dramatic inhibitory effects seen with $\alpha$-IR3, addition of antibody against the IGF- 
II/M6P receptor had no effect on cell proliferation. We used this antibody at $150 \mu \mathrm{g} / \mathrm{ml}$, a concentration known to block $90 \%$ of IGF-II binding to the IGFII/M6P receptor [10]. In a study using rhabdomyosarcoma cells, Minniti and colleagues demonstrated that the IGF-II/M6P receptor antibody prevents IGF-II induced cell motility but has only a small stimulatory effect on IGF-II autocrine growth [10]. Their results suggest that IGF-II binding to the IGF-II/M6P receptor has little growth-promoting effect, and may even inhibit rhabdomyosarcoma cell growth. Just as in our experiments, they found that IGF-II promotes autocrine proliferation through interaction with the type I IGF receptor.

There is a growing body of literature indicating that the type I IGF receptor may, via its tyrosine kinase signal transduction mechanism, be tightly linked to regulation of cellular proliferation [26]. It is well known that insulin, IGF-I, and IGF-II, acting through the type I IGF receptor, can stimulate cell division in a variety of tissues and cell types [27]. Although this receptor has not been shown to play a direct role in cellular transformation, overexpression of the receptor and one or more of its ligands in a tissue may very well be part of the mechanism leading to tumorigenesis. IGF-II and the type I IGF receptor are commonly over-expressed in many transformed cell types, including breast cancer [22,28], Wilm's tumors [29], neuroblastomas [5], and rhabdomyosarcoma [24], and could reflect a common theme in carcinogenesis.

In contrast to the type I IGF receptor, IGF-II binding to the IGF-II/M6P receptor appears not to play an important role in neuroblastoma cell division. Alternatively, this receptor may be associated with an IGF-II differentiation pathway. Ishii and colleagues have demonstrated that IGF-II enhances neuritic outgrowth in SH-SY5Y cells in serum-free media [30], and we have provided evidence that this effect may involve the IGF-II/M6P receptor [11]. It is possible, then, that IGF-II acting through the IGFII/M6P receptor promotes a neuroblastoma cell differentiation pathway. Further experiments will be necessary to determine whether blocking the IGFII/M6P receptor has any effect on the development of a mature, differentiated neuroblastoma cell phenotype.

\section{IGF receptor expression}

We detected increased expression of both type I IGF receptor and IGF-II/M6P receptor mRNA levels over a 3-day period in serum and serum-free media. Type I IGF receptor $\mathrm{mRNA}$ increased more dramatically than IGF-II/M6P receptor mRNA (6fold compared to 2-fold), suggesting that expression of the type I IGF receptor gene may be more sensitive to growth regulation. Elevated type I IGF receptor RNA has also been observed under various conditions of altered growth and differentiation, such as after treatment of SH-SY5Y cells with interferon- $\gamma$ [31] or phorbol ester [32], with liver differentiation [33], and during fetal rat development [34]. Altered expression of the type I IGF receptor therefore seems to correlate with changes in cell and tissue growth rate. Påhlman and colleagues have shown that this receptor promotes IGF-I induced SH-SY5Y cell proliferation, or differentiation if the cells are treated with phorbol ester [35]. Thus, factors in serum which regulate cell growth rate may also control type I IGF receptor function and expression. For example, IGFs present in serum and IGF-II produced by SHSY5Y cells could mediate the increased type I IGF receptor mRNA observed over time in culture, in which case addition of antibody against type I IGF receptor mRNA would be expected to block the increase.

IGF-II/M6P receptor mRNA levels increased 2-fold in SH-SY5Y cells under serum or serum-free conditions. We have previously shown that IGF-II mRNA levels are also increased in SH-SY5Y cells during exposure to serum or serum-free media [6], indicating that IGF-II and its receptors may be coordinately regulated. Consistent with this idea are data from Szebenyi and colleagues, who demonstrated coordinately increased IGF-II and IGF-II/ M6P receptor mRNA during IGF-II/M6P receptor- 
mediated mouse muscle cell differentiation in serumfree media [36]. The IGF-II/M6P receptor does not seem to play a role in IGF-II mediated SH-SY5Y cell division, and it is therefore not surprising that serum and serum removal had only 2-fold effects on receptor expression.

The IGF-II/M6P receptor is developmentally expressed in the rat, with high fetal levels in serum and in several tissues including brain, and 100-fold lower levels in the adult [37]. Up-regulation of this receptor has also been observed during rat liver regeneration [38] and mouse muscle cell differentiation [36]. The significance of increased IGF-II/M6P receptor in SH-SY5Y cells is not yet known. In a study using mouse L-cells, Einstein and Gabel showed that serum factors, including IGF-II, regulate dephosphorylation of lysosomal hydrolases via the IGF-II/M6P receptor [39]. It is possible that IGF-II serves a similar role in SH-SY5Y cells.

In conclusion, the results of experiments presented here provide strong evidence that IGF-II promotes SH-SY5Y neuroblastoma cell autocrine growth through interaction with the type I IGF receptor and not with the IGF-II/M6P receptor. Expression of both receptors is altered with changes in serum concentration, and may be associated with the effects of serum on cell growth rate. Further experiments will help determine the role of IGF-II and its receptors in proliferation and differentiation of both cancerous and non-cancerous cell types.

\section{Acknowledgements}

We thank Dr. William S. Sly (St. Louis University Medical Center, St. Louis, MO) for providing the cDNA and antisera for human IGF-II/M6P receptor. Drs. Axel Ullrich and Donald Cleveland provided cDNAs for type I IGF receptor and $\beta$-actin, respectively. D.M.M. was supported by NIH training grant NS $07222-09$ and E.L.F. by NIH grant NS01380.

\section{References}

1 Rotwein, P., Structure, evolution, expression and regulation of insulin-like growth factors I and II, Growth Factors, 5 (1991) 3-18.

2 Bothwell, M., Insulin and somatomedin MSA promote nerve growth factor-independent neurite formation by cultured chick dorsal root ganglionic sensory neurons, J. Neurosci. Res., 8 (1982) 225-231.

3 Recio-Pinto, E., Rechler, M.M. and Ishii, D.N., Effects of insulin, insulin-like growth factor-II, and nerve growth factor on neurite formation and survival in cultured sympathetic and sensory neurons, J. Neurosci., 6 (1986) 1211-1219.

4 DiCicco-Bloom, E. and Black, I.B., Insulin growth factors regulate the mitotic cycle in cultured rat sympathetic neuroblasts, Proc. Natl. Acad. Sci. USA, 85 (1988) 4066-4070.

5 El-Badry, O.M., Romanus, J.A., Helman, L.J., Cooper, M.J., Rechler, M.M. and Israel, M.A., Autonomous growth of a human neuroblastoma cell line is mediated by insulin-like growth factor II, J. Clin. Invest., 84 (1989) 829-839.

6 Martin, D.M. and Feldman, E.L., Regulation of insulin-like growth factor-II expression and its role in autocrine growth of human neuroblastoma cells, J. Cell. Physiol., in press.

7 Roth, R.A., Structure of the receptor for insulin-like growth factor II: the puzzle amplified, Science, 239 (1988) 1269-1271.

8 Morgan, D.O., Jarnagin, K. and Roth, R.A., Purification and characterization of the receptor for insulin-like growth factor I, Biochemistry, 25 (1986) 5560-5564.

9 Roth, R.A., Stover, C., Hari, J., Morgan, D.O., Smith, M.C., Sara, V. and Fried, V.A., Interactions of the receptor for insulin-like growth factor II with mannose-6-phosphate and antibodies to the mannose-6-phosphate receptor, Biochem. Biophys. Res. Commun., 149 (1987) 600-606.

10 Minniti, C.P., Kohn, E.C., Grubb, J.H., Sly, W.S., Oh, Y., Múller, H.L., Rosenfeld, R.G. and Helman, L.J., The insulinlike growth factor II (IGF-II)/mannose 6-phosphate receptor mediates IGF-II-induced motility in human rhabdomyosarcoma cells, J. Biol. Chem., 267 (1992) 9000-9004.

11 Feldman, E.L. and Randolph, A.E., Mannose 6-phosphate potentiates insulin-like growth factor II effects in cultured human neuroblastoma cells, Brain Res., 562 (1991) 111-116.

12 Okamoto, T., Asano, T., Harada, S., Ogata, E. and Nishimoto, I., Regulation of transmembrane signal transduction of insulin-like growth factor II by competence type growth factors or viral ras p21, J. Biol. Chem., 266 (1991) 1085-1091.

13 Rogers, S.A. and Hammerman, M.R., Mannose 6-phosphate potentiates insulin-like growth factor II-stimulated inositol trisphosphate production in proximal tubular basolateral membranes, J. Biol. Chem., 264 (1989) 4273-4276.

14 Humbel, R.E., Insulin-like growth factors I and II, Eur. J. Biochem., 190 (1990) 445-462. 
15 Martin, D.M., Yee, D., Carlson, R.O. and Feldman, E.L., Gene expression of the insulin-like growth factors and their receptors in human neuroblastoma cells, Mol. Brain Res., 15 (1992) 241-246.

16 Recio-Pinto, E. and Ishii, D.N., Insulin and insulinlike growth factor receptors regulating neurite formation in cultured human neuroblastoma cells, J. Neurosci. Res., 19 (1988) 312-320.

17 Biedler, J.L., Roffler-Tarlov, S., Schachner, M. and Freedman, L.S., Multiple neurotransmitter synthesis by human neuroblastoma cell lines and clones, Cancer Res., 38 (1978) 37513757.

18 Hansen, M.B., Nielsen, S.E. and Berg, K., Re-examination and further development of a precise and rapid dye method for measuring cell growth/cell kill, J. Immunol. Methods, 119 (1989) 203-210.

19 Ullrich, A., Gray, A., Tam, A.W., Yang-Feng, T., Le Bon, T., Kathuria, S., Chen, E., Jacobs, S., Francke, U., Ramachandran, J. and Fujita-Yamaguchi, Y., Insulin-like growth factor I receptor primary structure: comparison with insulin receptor suggests structural determinants that define functional specificity, EMBO J., 5 (1986) 2503-2512.

20 Oshima, A., Nolan, C.M., Kyle, J.W., Grubb, J.H. and Sly, W.S., The human cation-independent mannose 6-phosphate receptor, J. Biol. Chem., 263 (1988) 2553-2562.

21 Cleveland, D.W., Lopata, M.A., MacDonald, R.J., Cowan, N.J., Rutter, W.J. and Kirschner, M.W., Number and evolutionary conservation of $\alpha$ - and $\beta$-tubulin and cytoplasmic $\beta$ and $\gamma$-actin genes using specific cloned cDNA probes, Cell, 20 (1980) 95-105.

22 Cullen, K.J., Lippman, M.E., Chow, D., Hill, S., Rosen, N. and Zwiebel, J.A., Insulin-like growth factor-II overexpression in MCF-7 cells induces phenotypic changes associated with malignant progression, Mol. Endocrinol., 6 (1992) 91-100.

23 Florini, J.R., Magri, K.A., Ewton, D.Z., James, P.L., Grindstaff, K. and Rotwein, P.S., 'Spontaneous' differentiation of skeletal myoblasts is dependent upon autocrine secretion of insulin-like growth factor-II, J. Biol. Chem., 266 (1991) 15917-15923.

24 El-Badry, O.M., Minniti, C.P., Kohn, E.C., Houghton, P.J., Daughaday, W.J. and Helman, L.J., Insulin-like growth factor II acts as an autocrine growth and motility factor in human rhabdomyosarcoma tumors, Cell Growth Diff., 1 (1990) 325331.

25 Cross, M. and Dexter, T.M., Growth factors in development, transformation, and tumorigenesis, Cell, 64 (1991) 271280.

26 Daughaday, W.H., Editorial: The possible autocrine/paracrine and endocrine roles of insulin-like growth factors of human tumors, Endocrinology, 127 (1990) 1-4.

27 Sara, V.R. and Hall, K., Insulin-Like Growth Factors and Their Binding Proteins, Physiol. Rev., 70 (1990) 591-614.
28 Osborne, C.K., Coronado, E.B., Kitten, L.J., Arteaga, C.I., Fuqua, S.A.W., Ramasharma, K., Marshall, M. and Li, C.H., Insulin-like growth factor-II (IGF-II): a potential autocrine/ paracrine growth factor for human breast cancer acting via the IGF-I receptor, Mol. Endocrinol., 3 (1989) 1701-1709.

29 Drummond, I.A., Madden, S.L., Rohwer-Nutter, P., Bell, G.I., Sukhatme, V.P. and Rauscher, F.J.,III, Repression of the insulin-like growth factor II gene by the Wilms tumor suppressor WT1, Science, 257 (1992) 674-678.

30 Ishii, D.N., Wang, C. and Li, Y., Second messengers mediating gene expression essential to neurite formation directed by insulin and insulin-like growth factors, Adv. Exp. Med. Biol. 293 (1991) 361-378.

31 Martin, D.M., Carlson, R.O. and Feldman, E.L., Interferon- $\gamma$ inhibits DNA synthesis and IGF-II gene expression in human neuroblastoma cells, J. Neurosci. Res., 34 (1992) 489-501.

32 Ota, A., Shen-Orr, Z., Roberts, C.T.,Jr. and LeRoith, D., TPA-induced neurite formation in a neuroblastoma cell line (SH-SY5Y) is associated with increased IGF-I receptor mRNA and binding, Mol. Brain Res., 6 (1989) 69-76.

33 Rosenthal, S.M., Brown, E.J., Brunetti, A. and Goldfine, I.D., Fibroblast growth factor inhibits insulin-like growth factor-II (IGF-II) gene expression and increases IGF-I receptor abundance in BC3H-1 muscle cells, Mol. Endocrinol., 5 (1991) 678-684.

34 Bondy, C.A., Werner, H., Roberts, C.T. Jr. and LeRoith, D., Cellular pattern of insulin-like growth factor-I (IGF-I) and type I IGF receptor gene expression in early organogenesis: comparison with IGF-II gene expression, Mol. Endocrinol., 4 (1990) 1386-1398.

35 Påhlman, S., Meyerson, G., Lindgren, E., Schalling, M. and Johansson, I., Insulin-like growth factor I shifts from promoting cell division to potentiating maturation during neuronal differentiation, Proc. Natl. Acad. Sci. USA, 88 (1991) 9994 9998.

36 Szebenyi, G. and Rotwein, P., Differential regulation of mannose 6-phosphate receptors and their ligands during the myogenic development of C2 cells, J. Biol. Chem., 266 (1991) 5534-5539.

37 Ballesteros, M., Scott, C.D. and Baxter, R.C., Developmental regulation of insulin-like growth factor-II/mannose 6-phosphate receptor mRNA in the rat, Biochem. Biophys. Res. Commun., 172 (1990) 775-779.

38 Jirtle, R.L., Carr, B.I. and Scot, C.D., Modulation of insulinlike growth factor-II/Mannose 6-phosphate receptors and transforming growth factor beta-1 during liver regeneration, $\mathbf{J}$. Biol. Chem., 266 (1991) 22444-22450.

39 Einstein, R. and Gabel, C.A., Serum factors alter the extent of dephosphorylation of ligands endocytosed via the mannose 6-phosphate/insulin-like growth factor II receptor, J. Cell Biol., 109 (1989) 1037-1046. 